\title{
Natural Killer Cell-Based Immunotherapy against Solid Cancer
}

\author{
Pinlei Lv, Wenrui Li, Ruoyu Wang, Guojun Huang, Yi Zhu, Qiqiang Tao \\ Hainan Neology Stem Cell Anti-Aging Hospital, BoAo LeCheng International Medical Tourism Pilot Zone, Qionghai, China \\ Email: lvpinlei@beautech.net.cn
}

How to cite this paper: Lv, P.L., Li, W.R., Wang, R.Y., Huang, G.J., Zhu, Y. and Tao, Q.Q. (2021) Natural Killer Cell-Based Immunotherapy against Solid Cancer. Open Access Library Journal, 8: e7056. https://doi.org/10.4236/oalib.1107056

Received: November 30, 2020

Accepted: February 23, 2021

Published: February 26, 2021

Copyright $\odot 2021$ by author(s) and Open Access Library Inc.

This work is licensed under the Creative Commons Attribution International License (CC BY 4.0).

http://creativecommons.org/licenses/by/4.0/ (c) (i) Open Access

\begin{abstract}
As a kind of important innate lymphocytes in vivo, Natural killer (NK) cells have a rapid and efficient capacity to recognize and destroy tumor cells, senescent cells and virus-infected cells. In the past decades, NK cells have been widely applied in the treatment of hematological malignancies in clinic, even solid tumors. Successful results have been made against hematological malignancies (NCT00697671, NCT00990717, NCT00145626), but also a number of considerable challenges have been encountered during this period, such as poor outcomes in the treatment of solid tumors, difficult to migrate to and infiltrate into tumor sites, little functioning NK cell was seen in tumor stroma. Now we know tumor microenvironment has great influence on NK cell function, phenotype and activation, and it can finally give rise to NK cell dysfunction or/and exhaustion. Many strategies have been made to try to overcome those drawbacks. In this review, we discuss the current strategies to increase the NK cell-mediated tumor cell killing capacity and homing to the solid tumor site with the aim of heightening the clinical outcome in NK cell-based immunotherapy against solid cancer.
\end{abstract}

\section{Subject Areas}

Cell Biology

\section{Keywords}

Natural Killer Cell, Immunotherapy, Solid Cancer, Cytolytic Function

\section{Introduction}

Natural killer (NK) cells were first found in peripheral blood due to its function which could target and destroy leukemia cells [1]. The percentage of NK cells in all of lymphocytes was estimated about $10 \%-15 \%$, and its half-life was 
approximately 7 to 10 days in blood [2]. Later studies have found that NK cells are also located in distinct tissue sites, including liver, lung, bone marrow, thymus, intestine and lymph nodes, ect., where they exert unique roles in the particular tissues, and we named it tissue-resident NK cells (trNK) [3] [4] [5] [6]. Unlike B and T cells, NK cells in blood circulation could accurately recognize and lyse many kinds of cancer cells, senescent cells and virus-infected cells without prior sensitization [7] [8] [9]. We now know that mature NK cells are a heterogeneous population in humans which could be divided into two subsets: $\mathrm{CD}^{-} \mathrm{CD} 16^{+} \mathrm{CD} 56^{\text {bright }}$ and $\mathrm{CD}^{-} \mathrm{CD} 16^{-} \mathrm{CD} 56^{\mathrm{dim}}[10]$, each subset performs different roles in vivo, like $\mathrm{CD} 3^{-} \mathrm{CD} 16^{+} \mathrm{CD} 56^{\text {bright }}$ mainly for immune regulation through producing cytokines, such as interferon- $\gamma$ (IFN- $\gamma)$, tumor necrosis factor- $\alpha$ (TNF- $\alpha$ ) ect., another subset $\mathrm{CD}^{-} \mathrm{CD} 16^{-} \mathrm{CD} 56^{\text {dim }}$ mainly for cytotoxic effect which has been mostly applied for killing cancer cells in the immunotherapy against both hematologic and solid cancers in clinic [11]. However, in mice, mature NK cells are usually expressing CD27 and CD11b in circulation, and they are grouped into four subsets by surface density: $\mathrm{CD} 11 \mathrm{~b}^{\text {low }} \mathrm{CD} 27^{\text {low }}$, $\mathrm{CD} 11 \mathrm{~b}^{\text {low }} \mathrm{CD} 27^{\text {high }}, \mathrm{CD} 11 \mathrm{~b}^{\text {high }} \mathrm{CD} 27^{\text {high }}$, and $\mathrm{CD} 11 \mathrm{~b}^{\text {high }} \mathrm{CD} 27^{\text {low }}$ as described in Laura et al. [12].

There are a number of receptors expressed in NK cell membrane, they could be divided into activating and inhibitory receptors according to their different functions. Those receptors can recognize ligand protein expressed in the target cells, thereby controlling the cytolytic function and cytokines-produced function. Uniquely, they can discriminate between normal and abnormal cells via "missing-self" or "induced-self" recognition models [13] [14]. Inhibitory receptors can transmit negative signals that block NK cell auto-reactivity, and many researchers have found major histocompatibility complex (MHC) class I molecules (also known human leukocyte antigens (HLA) class I in humans), whose absence may lead to NK activation, are tightly recognized by inhibitory receptors, which is the so-called "missing-self recognition" [14] [15]. The most important inhibitory receptors in humans are represented by killer cell immunoglobulin like receptors (KIRs) specific for allotypic determinants shared by groups of HLA-A, -B or -C alleles [16]. In the later studies, scientists found it was not sufficient to induce NK cell activation by the absence expression of MHC molecules, but rather signaling from activating receptors was necessary, such as NKG2D, which is the so-called "induced-self recognition" [17] [18] [19]. Now it has a consistency that the balance between signals from those two kinds of receptors governs the activation or inhibition of NK cells, these cells remain homeostasis in vivo due to the predominance of inhibitory signals over activating signals, but when signals from activating receptors prevail, NK cells will respond immediately for cytolytic effect [20].

Activating receptors expressed in NK cell membrane, such as NKG2D, NKp30 and NKp46, are considered the most relevant receptors in the process of activating NK cells. Once activated, NK cells can destroy tumor cells, senescent cells 
and virus-infected cells by releasing the cytotoxic molecules perforin and granzyme, leading to the increasing expression of Fas ligand (FASL), TNF-related apoptosis-inducing ligand (TRAIL) and inflammatory cytokines and by antibody-dependent cellular cytotoxicity (ADCC) [21] [22] [23]. In addition to their direct cytotoxic function against abnormal cells, NK cells also have a specific role in the homeostasis of the immune system, especially initiate other immune cells (T cell, B cell, DC cell, macrophage ect.) activation via secreting cytokines and chemokines [24]. NK cells indirectly increase the immune responses of $\mathrm{T}$ cells by facilitating DC maturation [25]. Many scientific findings have come to the conclusion that NK cells can promote the antiviral activity of CD8+ T cells effect and moderate T cells exhaustion [26] [27].

NK cells with the powerful killing capacity have been used in clinic to getting successful results in the treatment of hematological malignancies, such as acute myeloid leukemia [28] [29], malignant lymphoma [30], relapsed and refractory leukemia [31] et al., but the clinical outcomes in the solid tumor were not satisfied, later studies show that NK cells function, phenotype and activation are severe damaged by the tumor microenvironment, even gave rise to NK cells dysfunctional or exhausted [32] [33]. Another challenge is that NK cell is hard to migrate to and infiltrate into the tumor sites, as a result, NK cells cannot effectively recognize and lyse the target cancerous cells. Thus, it is really essential to develop effective methods to increase the homing of NK cell to the tumor stroma and the cytolytic function. In the review, we discuss the current strategies and further optimize these strategies to enhance the clinical outcome of NK cell-based immunotherapy against solid cancer.

\section{NK Cell in Cancer Immunosurveillance}

Although owing the potent killing capacity, NK cells still face major challenges that dampen their clinical outcome in the complicated microenvironment in vivo. Many experiments have found that human NK cells, infiltrated into the tumor sites, have changed expression of activating and inhibitory receptors in surface and damaged its cytolytic functions [34] [35]. A number of signal pathways regulate NK cell suppression in the tumor microenvironment, several of which also give rise to impairing the $\mathrm{T}$ cells role [36]. It is thought that cancer cells have the capacity to evade immunosurveillance by shedding ligands which are expressed on the transformed cell membranes and can bind to the NKG2D activating receptors on NK cells. Recently, releasing of soluble NKG2D ligands have been drawn a great deal of attention due to its regulating process for NK cells activation. The soluble NKG2D ligands bind NKG2D receptors on NK cell surface, which could prevent their function to engage with the ligands on cancer cell membrane that would exert a cytolytic role [37] [38]. Using antibodies to target the soluble ligands has proved successful in multiple fully immunocompetent mouse models and reduced human melanoma metastases in a humanized mouse model [39]. However, Deng et al. found the opposite role of the soluble 
NKG2D ligands, which increase NK cells cytolytic function, as in the case of soluble MULT1, which prevented NK cell desensitization in the animal cancer model [40]. Those results demonstrate that soluble ligands show distinct role in a specific microenvironment and it needs to be more investigated.

\section{Immunosuppressive Effect by Tumor Microenvironment}

Cells isolated from the tumor microenvironment in hepatocellular carcinoma [41] and cancer-associated fibroblasts(CAF) patients [42] [43] [44] may have suppressive functions against NK cells, such as myeloid-derived suppressor cell (MDSCs) and tumor-associated macrophages (TAM), which can constitute an intricate tumor microenvironment together that restrain NK cell activity by changing the balance between NK activating and inhibitory receptors in favors of impaired immunity [45] [46] [47]. As reported in recent years, the role of NK cells in tumor microenvironment in ovarian cancer patients is severely impaired, whereas their counterpart exhibit normal function compared to that of healthy controls [48]. There are a large number of immunosuppressive cytokines and the other soluble molecules that have a great influence on NK cell maturation, proliferation and functionality in tumor microenvironment, including TGF- $\beta$, TNF- $\alpha$, IFN- $\gamma$, indoleamine 2,3-dioxygenase (IDO), IL-4, prostaglandin E2 (PGE2), lactate dehydrogenase A (LDHA) et al. [43] [49]-[55]. Those cytokines, especially TGF- $\beta$ mainly secreted by CAF in tumor microenvironment [56], could induce down expression of NKG2D in membrane, and finally leading to a diminished cytotoxicity of NK cells [57], also CAFs can recruit monocytes into the TME to promote polarization of M2 macrophages and drive inhibition of NK cell function [58]. Apart from the impaired cytotoxicity, TGF- $\beta$ can change the anti-metastatic function [59], metabolism [60] and mitochondrial role [61] in NK cells. Some experiment results show that NK cells can also transform to type 1 innate lymphoid cells by non-canonical TGF- $\beta$ signaling, allowing for tumor growth and metastasis in mice [62] [63]. Cancerous cells have the ability to escape the attack by NK cell, due to the prevention of cell contact. An anti-adhesion glycoprotein mucin 16 (MUC16) are continuously expressing on the ovarian cancerous cell membrane, which can inhibit synapse formation between NK and cancerous cells [64].

\section{Adoptive NK Cell Immunotherapy against Solid Cancer}

For NK cell-based immunotherapy against human cancers, it is much easier for NK cell to get access to hematological malignancies compared with the immunosuppressive microenvironment of solid cancers [65]. and NK cells are the first subtype of innate lymphoid cells to recovery after human allogeneic hematopoietic stem cell transplantation (HSCT) [66]. So NK cells are mostly used as a "star cell" in the immunotherapy against hematological malignancies as well as $\mathrm{T}$ cells. But recent years, there are more than 80 clinical trials (https://www.clinicaltrials.gov/) to assess the NK cell-based immunotherapy in 
variety of solid cancers, either as monotherapy, or combined with other regents.

Autologous NK cells have been applied for immunotherapy against solid tumors, such as advanced and/or metastatic digestive cancer, metastatic melanoma, renal cell carcinoma, but clinical responses were not observed after intravenous infusion [67] [68]. It is also found that autologous NK cells are not able to expand ex vivo in numbers for clinical infusion [69], this could be due to the radiotherapy or chemotherapy treatments, which can destroy both cancerous and normal cells, received by the patients before NK cell isolation from the peripheral blood, which may provide the explain for poor clinical outcomes. Some studies also show that allogeneic NK cell infusion has the promising clinical results in the treatment of pediatric refractory solid tumors, advanced non-small cell lung cancer and advanced solid tumors [30] [70] [71], it is not only safe and feasible, but also exhibited clinically effective. The human cell line NK92 has also been a cell source of allogeneic NK cell-based immunotherapy in clinic, and have observed encouraging clinical responses in advanced lung carcinoma patients, but its lifespan in patients peripheral blood is rarely limited, and only persists for $48 \mathrm{~h}$ [72] [73] [74]. Considering the source of NK92, more investigations should be conducted to validate the safety in the clinic. As for off-the-shelf NK cells, pluripotent stem cell could be differentiated into NK cell in vitro, and exert effective cytolytic function against cancerous cells, both in vivo and in vitro in animal model [75] [76] [77]. But these pluripotent stem cell-derived NK cells have not been applied in the clinical treatment due to its unverified safety and effectiveness in human. With the encouraging success of CAR-T cells for hematological malignancies treatment, there is a growing interest in developing CAR-NK cells for immunotherapy in both hematological malignancies and solid cancer in vivo. The most common target antigens in solid cancerous cells were constructed including EGFR [78], EGFRvIII [78] [79], HER-2 [80], PSMA [81], ROBO1 [82], MUC-1 [83] [84], CS1 [85] and Mesothelin [86] et al.. Although with various target antigens in the CAR-NK cell field, but limited progress we have made in clinic so far, especially for the solid tumor immunotherapy. Only eight clinical trials were registered to assessing the safety and effectiveness of CAR-NK cells in solid tumor patients, all of those trials are ongoing currently.

\section{Strategies to Improving Outcomes of NK Cell-Based Immunotherapy}

Many studies have come to the conclusion that the tumor microenvironment was the major factor that resulting tumor escape from NK cell anti-tumor immunity against solid cancers [45] [46] [87]. Thus efforts must be concentrated on the following aspects to augmenting the clinical outcomes of NK cell-based immunotherapy: 1) increasing the number of functioning NK cells in tumor stroma; 2) recuperating damaged metabolism and effectors roles in order to boost the cytotoxicity of NK cells against cancerous cells.

As we described above, a high concentration of TGF- $\beta$ secreted by TME blocks local NK cell anti-tumor immunity response. A study found that TGF- $\beta$ 
receptor-I inhibitor SB505124 could give rise to incredible increased percentages and absolute numbers of NK cells in the tumor site in metastatic B16 melanoma murine models [88]. Another study showed that the use of TGF- $\beta$ inhibitor, TGF- $\beta$ receptor kinase inhibitor LY2157299, could increase NK cell infiltration into liver tissue in a model of colon cancer metastasis [89]. Young et al. [90] have found that both $\mathrm{A} 2 \mathrm{AR}$ inhibitor and A2AR gene knockdown could target A2AR/ADO signaling to augment the accumulation of NK cells which have a highly cytolytic function, and finally leading to inhibition of tumor progression. Local administration of Car-T cell has been done in patients with solid cancers, such as breast cancer, malignant mesothelioma, medulloblastoma and colorectal cancer, and great success has been achieved in ClinicalTrials in recently years [91] [92] [93] [94]. Following those train of thoughts, an ongoing phase I clinical study, aiming at recurrent HER2-positive glioblastoma with the number of $1 \times$ $10^{7}$ to $1 \times 10^{8}$ by intracranial injection of NK-92/5.28.z cells, has been recruiting 30 participants (NCT03383978).

The lifespan of NK cells in blood circulation was really short, and they exhibit finite persistence in vivo [95], which can restrict their therapeutic efficiency in clinic. A Clinical Trial conducted by Bachanova shows that the persistence of NK cell has been greatly elevated by infusing IL-2 in adoptively transferred haploidentical NK cell in patients with refractory acute myeloid leukemia [96]. The similar study was finished in liver metastases of gastrointestinal carcinoma by infusing NK cells combined with IL-2 and Cetuximab [97], but the immune activation by IL-2 is not specific for NK cell, as it can also activate other immune cells, such as Tregs [98]. IL-15 has the significant effect on NK cell function [99], a number of studies have shown that NK cells with longer persistence, higher proliferative capacity and stronger cytotoxicity were got in vivo and in vitro by adding IL-15 or combining other cytokines, such as IL-12, IL-18 and IL-21 [100] [101] [102] [103]. the application of recombinant IL-15 in treating patients with different kinds of advanced solid cancers has been completed recently (NCT01727076), but no result was published until now. Apart from the cytokines stimulation, targeting metabolic pathways linked to survival could be another hopeful method to boost their persistence. Direct activation of citrate-malate shuttle by activating the transcription factor Srebp has been shown a promising strategy to promote glucose metabolism and cytolytic function of NK cell, and finally could have a role in enhancing their persistence [104]. Blocking glycolytic metabolism with 2-NBDG [105] or inhibiting Akt [106] could be another valuable therapeutic strategy which both have been elucidated on CD8+ T cells. All that being said, metabolic network about NK cell has not been fully understood, so more efforts should be devoted to clarify the mechanism about the overall network.

\section{Conclusion}

NK cells have been found for approximately 40 years, and they have become 
great potential killer against cancerous cells for its board cytotoxicity and good safety. Despite many challenges in clinic we have to meet, researchers still apply NK cells alleviating the patients' pain to some extend which is suffering from the solid cancers. A number of preclinical and clinical trials have been developed with the precise available methodologies, such as engineered NK cell (TGF- $\beta$-resistant NK cell [107] [108], CAR-NK cell [109] [110] [111]), NK-92 cell line [72] [73] [112], autologous or allogeneic NK cell combined with small molecules [103] [113] [114] [115]. The clinical therapeutic efficiency is not satisfied due to its persistence and difficulty to infiltration into the tumor sites. As we mentioned above, the key areas of developing strategies to improving clinical efficiency may mainly concentrate on homing of functioning NK cell in tumor sites and restoring activity to enhancing the cytolytic functions. It is most likely that the most beneficial therapeutic responses will be seen with the combination therapies.

\section{Acknowledgements}

This work is supported by CEO of Neology Zhu Yi and Business director of Neology Huang Guojun and Wang Ruoyu. The director of hospital Tao Qiqiang kindly gives advices to select the topic and supervise the manuscript. Li Wenrui assists to search papers related to NK cell immunotherapy.

\section{Conflicts of Interest}

The authors declare no conflicts of interest regarding the publication of this paper.

\section{References}

[1] Kiessling, R., Klein, E. and Wigzell, H. (1975) "Natural" Killer Cells in the Mouse. I. Cytotoxic Cells with Specificity for Mouse Moloney Leukemia Cells. Specificity and Distribution According to Genotype. European Journal of Immunology, 5, 112-117. https://doi.org/10.1002/eji.1830050208

[2] Campbell, K.S. and Hasegawa, J. (2013) Natural Killer Cell Biology: An Update and Future Directions. The Journal of Allergy and Clinical Immunology, 132, 536-544. https://doi.org/10.1016/j.jaci.2013.07.006

[3] Choucair, K., Duff, J.R., Cassidy, C.S., Albrethsen, M.T., Kelso, J.D., Lenhard, A., et al. (2019) Natural Killer Cells: A Review of Biology, Therapeutic Potential and Challenges in Treatment of Solid Tumors. Future Oncology, 15, 3053-3069. https://doi.org/10.2217/fon-2019-0116

[4] Dogra, P., Rancan, C., Ma, W., Toth, M., Senda, T., Carpenter, D.J., et al. (2020) Tissue Determinants of Human NK Cell Development, Function, and Residence. Cell, 180, 749-763.e713. https://doi.org/10.1016/j.cell.2020.01.022

[5] Hashemi, E. and Malarkannan, S. (2020) Tissue-Resident NK Cells: Development, Maturation, and Clinical Relevance. Cancers, 12, 1553. https://doi.org/10.3390/cancers12061553

[6] Peng, H. and Tian, Z. (2017) Diversity of Tissue-Resident NK Cells. Seminars in Immunology, 31, 3-10. https://doi.org/10.1016/j.smim.2017.07.006 
[7] Dahlberg, C.I., Sarhan, D., Chrobok, M., Duru, A.D. and Alici, E. (2015) Natural Killer Cell-Based Therapies Targeting Cancer: Possible Strategies to Gain and Sustain Anti-Tumor Activity. Frontiers in Immunology, 6, 605. https://doi.org/10.3389/fimmu.2015.00605

[8] Krizhanovsky, V., Yon, M., Dickins, R.A., Hearn, S., Simon, J., Miething, C., et al. (2008) Senescence of Activated Stellate Cells Limits Liver Fibrosis. Cell, 134, 657-667. https://doi.org/10.1016/j.cell.2008.06.049

[9] Hueber, B., Curtis II, A.D., Kroll, K., Varner, V., Jones, R., Pathak, S., et al. (2020) Functional Perturbation of Mucosal Group 3 Innate Lymphoid and Natural Killer Cells in Simian-Human Immunodeficiency Virus/Simian Immunodeficiency Virus-Infected Infant Rhesus Macaques. Journal of Virology, 94, e01644-19. https://doi.org/10.1128/JVI.01644-19

[10] Freud, A.G., Mundy-Bosse, B.L., Yu, J. and Caligiuri, M.A. (2017) The Broad Spectrum of Human Natural Killer Cell Diversity. Immunity, 47, 820-833. https://doi.org/10.1016/j.immuni.2017.10.008

[11] Stabile, H., Fionda, C., Gismondi, A. and Santoni, A. (2017) Role of Distinct Natural Killer Cell Subsets in Anticancer Response. Frontiers in Immunology, 8, 293. https://doi.org/10.3389/fimmu.2017.00293

[12] Chiossone, L., Chaix, J., Fuseri, N., Roth, C., Vivier, E. and Walzer, T. (2009) Maturation of Mouse NK Cells Is a 4-Stage Developmental Program. Blood, 113, 5488-5496. https://doi.org/10.1182/blood-2008-10-187179

[13] Long, E.O., Kim, H.S., Liu, D., Peterson, M.E. and Rajagopalan, S. (2013) Controlling Natural Killer Cell Responses: Integration of Signals for Activation and Inhibition. Annual Review of Immunology, 31, 227-258. https://doi.org/10.1146/annurev-immunol-020711-075005

[14] Abel, A.M., Yang, C., Thakar, M.S. and Malarkannan, S. (2018) Natural Killer Cells: Development, Maturation, and Clinical Utilization. Frontiers in Immunology, 9, 1869. https://doi.org/10.3389/fimmu.2018.01869

[15] Khanna, R. (1998) Tumour Surveillance: Missing Peptides and MHC Molecules. Immunology and Cell Biology, 76, 20-26. https://doi.org/10.1046/j.1440-1711.1998.00717.x

[16] Locatelli, F., Moretta, F., Brescia, L. and Merli, P. (2014) Natural Killer Cells in the Treatment of High-Risk Acute Leukaemia. Seminars in Immunology, 26, 173-179. https://doi.org/10.1016/j.smim.2014.02.004

[17] Cerwenka, A., Baron, J.L. and Lanier, L.L. (2001) Ectopic Expression of Retinoic Acid Early Inducible-1 Gene (RAE-1) Permits Natural Killer Cell-Mediated Rejection of a MHC Class I-Bearing Tumor in Vivo. Proceedings of the National Academy of Sciences of the United States of America, 98, 11521-11526. https://doi.org/10.1073/pnas.201238598

[18] Diefenbach, A., Jamieson, A.M., Liu, S.D., Shastri, N. and Raulet, D.H. (2000) Ligands for the Murine NKG2D Receptor: Expression by Tumor Cells and Activation of NK Cells and Macrophages. Nature Immunology, 1, 119-126.

https://doi.org/10.1038/77793

[19] Diefenbach, A., Jensen, E.R., Jamieson, A.M. and Raulet, D.H. (2001) Rae1 and H60 Ligands of the NKG2D Receptor Stimulate Tumour Immunity. Nature, 413, 165-171. https://doi.org/10.1038/35093109

[20] Martinet, L. and Smyth, M.J. (2015) Balancing Natural Killer Cell Activation through Paired Receptors. Nature Reviews Immunology, 15, 243-254.

https://doi.org/10.1038/nri3799 
[21] Takeda, K., Hayakawa, Y., Smyth, M.J., Kayagaki, N., Yamaguchi, N., Kakuta, S., et al. (2001) Involvement of Tumor Necrosis Factor-Related Apoptosis-Inducing Ligand in Surveillance of Tumor Metastasis by Liver Natural Killer Cells. Nature Medicine, 7, 94-100. https://doi.org/10.1038/83416

[22] Fauriat, C., Long, E.O., Ljunggren, H.G. and Bryceson, Y.T. (2010) Regulation of Human NK-Cell Cytokine and Chemokine Production by Target Cell Recognition. Blood, 115, 2167-2176. https://doi.org/10.1182/blood-2009-08-238469

[23] Bryceson, Y.T., Ljunggren, H.G. and Long, E.O. (2009) Minimal Requirement for Induction of Natural Cytotoxicity and Intersection of Activation Signals by Inhibitory Receptors. Blood, 114, 2657-2666.

https://doi.org/10.1182/blood-2009-01-201632

[24] Vivier, E., Raulet, D.H., Moretta, A., Caligiuri, M.A., Zitvogel, L., Lanier, L.L., et al. (2011) Innate or Adaptive Immunity? The Example of Natural Killer Cells. Science, 331, 44-49. https://doi.org/10.1126/science.1198687

[25] Moretta, A., Marcenaro, E., Parolini, S., Ferlazzo, G. and Moretta, L. (2008) NK Cells at the Interface between Innate and Adaptive Immunity. Cell Death and Differentiation, 15, 226-233. https://doi.org/10.1038/sj.cdd.4402170

[26] Zheng, M., Sun, R., Wei, H. and Tian, Z.G. (2016) NK Cells Help Induce Anti-Hepatitis B Virus CD8 ${ }^{+} \mathrm{T}$ Cell Immunity in Mice. Journal of Immunology, 196, 4122-4131. https://doi.org/10.4049/jimmunol.1500846

[27] Jiang, S.L., Zhu, Y., Cheng, C., Li, Y., Ma, T., Peng, Z.W., et al. (2020) NK Cells Contribute to Hepatic CD8 ${ }^{+} \mathrm{T}$ Cell Failure in Hepatitis B Virus-Carrier Mice after Alcohol Consumption. Virus Research, 286, Article ID: 198085.

https://doi.org/10.1016/j.virusres.2020.198085

[28] Boyiadzis, M., Agha, M., Redner, R.L., Sehgal, A., Im, A., Hou, J.-Z., et al. (2017) Phase 1 Clinical Trial of Adoptive Immunotherapy Using “Off-the-Shelf” Activated Natural Killer Cells in Patients with Refractory and Relapsed Acute Myeloid Leukemia. Cytotherapy, 19, 1225-1232. https://doi.org/10.1016/j.jcyt.2017.07.008

[29] Kottaridis, P.D., North, J., Tsirogianni, M., Marden, C., Samuel, E.R., Jide-Banwo, S., et al. (2015) Two-Stage Priming of Allogeneic Natural Killer Cells for the Treatment of Patients with Acute Myeloid Leukemia: A Phase I Trial. PLoS ONE, 10, e0123416. https://doi.org/10.1371/journal.pone.0123416

[30] Yang, Y., Lim, O., Kim, T.M., Ahn, Y.-O., Choi, H., Chung, H., et al. (2016) Phase I Study of Random Healthy Donor-Derived Allogeneic Natural Killer Cell Therapy in Patients with Malignant Lymphoma or Advanced Solid Tumors. Cancer Immunology Research, 4, 215-224. https://doi.org/10.1158/2326-6066.CIR-15-0118

[31] Vela, M., Corral, D., Carrasco, P., Fernández, L., Valentín, J., González, B., et al. (2018) Haploidentical IL-15/41BBL Activated and Expanded Natural Killer Cell Infusion Therapy after Salvage Chemotherapy in Children with Relapsed and Refractory Leukemia. Cancer Letters, 422, 107-117. https://doi.org/10.1016/j.canlet.2018.02.033

[32] Vitale, M., Cantoni, C., Pietra, G., Mingari, M.C. and Moretta, L. (2014) Effect of Tumor Cells and Tumor Microenvironment on NK-Cell Function. European Journal of Immunology, 44, 1582-1592. https://doi.org/10.1002/eji.201344272

[33] Cremer, I., Fridman, W.H. and Sautès-Fridman, C. (2012) Tumor Microenvironment in NSCLC Suppresses NK Cells Function. OncoImmunology, 1, 244-246. https://doi.org/10.4161/onci.1.2.18309

[34] Carrega, P., Morandi, B., Costa, R., Frumento, G., Forte, G., Altavilla, G., et al. (2008) Natural Killer Cells Infiltrating Human Nonsmall-Cell Lung Cancer Are 
Enriched in CD56 ${ }^{\text {Bright }} \mathrm{CD} 16^{-}$Cells and Display an Impaired Capability to Kill Tumor Cells. Cancer, 112, 863-875. https://doi.org/10.1002/cncr.23239

[35] Delahaye, N.F., Rusakiewicz, S., Martins, I., Ménard, C., Roux, S., Lyonnet, L., et al. (2011) Alternatively Spliced NKp30 Isoforms Affect the Prognosis of Gastrointestinal Stromal Tumors. Nature Medicine, 17, 700-707.

https://doi.org/10.1038/nm.2366

[36] Chambers, A.M., Lupo, K.B. and Matosevic, S. (2018) Tumor Microenvironment-Induced Immunometabolic Reprogramming of Natural Killer Cells. Frontiers in Immunology, 9, 2517. https://doi.org/10.3389/fimmu.2018.02517

[37] Zingoni, A., Vulpis, E., Nardone, I., Soriani, A., Fionda, C., Cippitelli, M., et al. (2016) Targeting NKG2D and NKp30 Ligands Shedding to Improve NK Cell-Based Immunotherapy. Critical Reviews in Immunology, 36, 445-460.

https://doi.org/10.1615/CritRevImmunol.2017020166

[38] Chitadze, G., Bhat, J., Lettau, M., Janssen, O. and Kabelitz, D. (2013) Generation of Soluble NKG2D Ligands: Proteolytic Cleavage, Exosome Secretion and Functional Implications. Scandinavian Journal of Immunology, 78, 120-129. https://doi.org/10.1111/sji.12072

[39] Ferrari de Andrade, L., Tay, R.E., Pan, D., Luoma, A.M., Ito, Y., Badrinath, S., et al. (2018) Antibody-Mediated Inhibition of MICA and MICB Shedding Promotes NK Cell-Driven Tumor Immunity. Science, 359, 1537-1542. https://doi.org/10.1126/science.aao0505

[40] Deng, W., Gowen, B.G., Zhang, L., Wang, L., Lau, S., Iannello, A., et al. (2015) Antitumor Immunity. A Shed NKG2D Ligand That Promotes Natural Killer Cell Activation and Tumor Rejection. Science, 348, 136-139. https://doi.org/10.1126/science.1258867

[41] Hoechst, B., Voigtlaender, T., Ormandy, L., Gamrekelashvili, J., Zhao, F., Wedemeyer, H., et al. (2009) Myeloid Derived Suppressor Cells Inhibit Natural Killer Cells in Patients with Hepatocellular Carcinoma via the NKp30 Receptor. Hepatology, 50, 799-807. https://doi.org/10.1002/hep.23054

[42] Li, T., Yang, Y., Hua, X., Wang, G., Liu, W., Jia, C., et al. (2012) Hepatocellular Carcinoma-Associated Fibroblasts Trigger NK Cell Dysfunction via PGE2 and IDO. Cancer Letters, 318, 154-161. https://doi.org/10.1016/j.canlet.2011.12.020

[43] Balsamo, M., Vermi, W., Parodi, M., Pietra, G., Manzini, C., Queirolo, P., et al. (2012) Melanoma Cells Become Resistant to NK-Cell-Mediated Killing When Exposed to NK-Cell Numbers Compatible with NK-Cell Infiltration in the Tumor. European Journal of Immunology, 42, 1833-1842. https://doi.org/10.1002/eji.201142179

[44] Li, T., Yi, S., Liu, W., Jia, C., Wang, G., Hua, X., et al. (2013) Colorectal Carcinoma-Derived Fibroblasts Modulate Natural Killer Cell Phenotype and Antitumor Cytotoxicity. Medical Oncology, 30, Article No. 663. https://doi.org/10.1007/s12032-013-0663-Z

[45] Nayyar, G., Chu, Y. and Cairo, M.S. (2019) Overcoming Resistance to Natural Killer Cell Based Immunotherapies for Solid Tumors. Frontiers in Oncology, 9, 51. https://doi.org/10.3389/fonc.2019.00051

[46] Habif, G., Crinier, A., André, P., Vivier, E. and Narni-Mancinelli, E. (2019) Targeting Natural Killer Cells in Solid Tumors. Cellular \& Molecular Immunology, 16, 415-422. https://doi.org/10.1038/s41423-019-0224-2

[47] Stojanovic, A. and Cerwenka, A. (2011) Natural Killer Cells and Solid Tumors. Journal of Innate Immunity, 3, 355-364. https://doi.org/10.1159/000325465 
[48] Carlsten. M., Norell. H., Bryceson. Y.T., Poschke, I., Schedvins, K., Ljunggren, H.-G., et al. (2009) Primary Human Tumor Cells Expressing CD155 Impair Tumor Targeting by Down-Regulating DNAM-1 on NK Cells. Journal of Immunology, 183, 4921-4930. https://doi.org/10.4049/jimmunol.0901226

[49] Bi, J. and Tian, Z. (2017) NK Cell Exhaustion. Frontiers in Immunology, 8, 760. https://doi.org/10.3389/fimmu.2017.00760

[50] Ghiringhelli, F., Ménard, C., Terme, M., Flament, C., Taieb, J., Chaput, N., et al. (2005) $\mathrm{CD}^{+} \mathrm{CD} 25^{+}$Regulatory T Cells Inhibit Natural Killer Cell Functions in a Transforming Growth Factor-Beta-Dependent Manner. The Journal of Experimental Medicine, 202, 1075-1085. https://doi.org/10.1084/jem.20051511

[51] Castriconi, R., Cantoni, C., Della Chiesa, M., Vitale, M., Marcenaro, E., Conte, R., et al. (2003) Transforming Growth Factor Beta 1 Inhibits Expression of NKp30 and NKG2D Receptors: Consequences for the NK-Mediated Killing of Dendritic Cells. Proceedings of the National Academy of Sciences of the United States of America, 100, 4120-4125. https://doi.org/10.1073/pnas.0730640100

[52] Marcenaro, E., Della Chiesa, M., Bellora, F., Parolini, S., Millo, R., Moretta, L., et al. (2005) IL-12 or IL-4 Prime Human NK Cells to Mediate Functionally Divergent Interactions with Dendritic Cells or Tumors. Journal of Immunology, 174, 3992-3998. https://doi.org/10.4049/jimmunol.174.7.3992

[53] Pietra, G., Manzini, C., Rivara, S., Vitale, M., Cantoni, C., Petretto, A., et al. (2012) Melanoma Cells Inhibit Natural Killer Cell Function by Modulating the Expression of Activating Receptors and Cytolytic Activity. Cancer Research, 72, 1407-1415. https://doi.org/10.1158/0008-5472.CAN-11-2544

[54] Batlle, E. and Massagué, J. (2019) Transforming Growth Factor- $\beta$ Signaling in Immunity and Cancer. Immunity, 50, 924-940.

https://doi.org/10.1016/j.immuni.2019.03.024

[55] Feng, Y., Xiong, Y., Qiao, T., Li, X., Jia, L., Han, Y., et al. (2018) Lactate Dehydrogenase A: A Key Player in Carcinogenesis and Potential Target in Cancer Therapy. Cancer Medicine, 7, 6124-6136. https://doi.org/10.1002/cam4.1820

[56] Augsten, M. (2014) Cancer-Associated Fibroblasts as Another Polarized Cell Type of the Tumor Microenvironment. Frontiers in Oncology, 4, 62. https://doi.org/10.3389/fonc.2014.00062

[57] Lee, J.C., Lee, K.M., Kim, D.W. and Heo, D.S. (2004) Elevated TGF-Betal Secretion and Down-Modulation of NKG2D Underlies Impaired NK Cytotoxicity in Cancer Patients. Journal of Immunology, 172, 7335-7340.

https://doi.org/10.4049/jimmunol.172.12.7335

[58] Zhang, R., Qi, F., Zhao, F., Li, G., Shao, S.L., Zhang, X.C., et al. (2019) Cancer-Associated Fibroblasts Enhance Tumor-Associated Macrophages Enrichment and Suppress NK Cells Function in Colorectal Cancer. Cell Death \& Disease, 10, Article No. 273. https://doi.org/10.1038/s41419-019-1435-2

[59] Viel, S., Marçais, A., Guimaraes, F.S., Loftus, R., Rabilloud, J., Grau, M., et al. (2016) TGF- $\beta$ Inhibits the Activation and Functions of NK Cells by Repressing the mTOR Pathway. Science Signaling, 9, ra19. https://doi.org/10.1126/scisignal.aad1884

[60] Zaiatz-Bittencourt. V., Finlay. D.K. and Gardiner. C.M. (2018) Canonical TGF- $\beta$ Signaling Pathway Represses Human NK Cell Metabolism. Journal of Immunology, 200, 3934-3941. https://doi.org/10.4049/jimmunol.1701461

[61] Slattery, K., Zaiatz-Bittencourt, V., Woods, E., Brennan, K., Marks, S., Chew, S., et al. (2019) TGF $\beta$ Drives Mitochondrial Dysfunction in Peripheral Blood NK Cells during Metastatic Breast Cancer. bioRxiv, Article ID: 648501. 
https://doi.org/10.1101/648501

[62] Cortez, V.S., Ulland, T.K., Cervantes-Barragan, L., Bando, J.K., Robinette, M.L., Wang, Q.L., et al. (2017) SMAD4 Impedes the Conversion of NK Cells into ILC1-Like Cells by Curtailing Non-Canonical TGF- $\beta$ Signaling. Nature Immunology, 18, 995-1003. https://doi.org/10.1038/ni.3809

[63] Gao, Y., Souza-Fonseca-Guimaraes, F., Bald, T., Ng, S.S., Young, A., Ngiow, S.F., et al. (2017) Tumor Immunoevasion by the Conversion of Effector NK Cells Into Type 1 Innate Lymphoid Cells. Nature Immunology, 18, 1004-1015. https://doi.org/10.1038/ni.3800

[64] Gubbels, J.A., Felder, M., Horibata, S., Belisle, J.A., Kapur, A., Holden, H., et al. (2010) MUC16 Provides Immune Protection by Inhibiting Synapse Formation between NK and Ovarian Tumor Cells. Molecular Cancer, 9, Article No. 11. https://doi.org/10.1186/1476-4598-9-11

[65] Mehta, R.S., Randolph, B., Daher, M. and Rezvani, K. (2018) NK Cell Therapy for Hematologic Malignancies. International Journal of Hematology, 107, 262-270. https://doi.org/10.1007/s12185-018-2407-5

[66] Mehta, R.S. and Rezvani, K. (2016) Immune Reconstitution Post Allogeneic Transplant and the Impact of Immune Recovery on the Risk of Infection. Virulence, 7, 901-916. https://doi.org/10.1080/21505594.2016.1208866

[67] Sakamoto, N., Ishikawa, T., Kokura, S., Okayama, T., Oka, K., Ideno, M., et al. (2015) Phase I Clinical Trial of Autologous NK Cell Therapy Using Novel Expansion Method in Patients with Advanced Digestive Cancer. Journal of Translational Medicine, 13, Article No. 277. https://doi.org/10.1186/s12967-015-0632-8

[68] Parkhurst, M.R., Riley, J.P., Dudley, M.E. and Rosenberg, S.A. (2011) Adoptive Transfer of Autologous Natural Killer Cells Leads to High Levels of Circulating Natural Killer Cells but Does Not Mediate Tumor Regression. Clinical Cancer Research, 17, 6287-6297. https://doi.org/10.1158/1078-0432.CCR-11-1347

[69] Geller, M.A., Cooley, S., Judson, P.L., Ghebre, R., Carson, L.F., Argenta, P.A., et al. (2011) A Phase II Study of Allogeneic Natural Killer Cell Therapy to Treat Patients with Recurrent Ovarian and Breast Cancer. Cytotherapy, 13, 98-107. https://doi.org/10.3109/14653249.2010.515582

[70] Pérez-Martínez, A., Fernández, L., Valentín, J., Martínez-Romera, I., Corral, M.D., Ramírez, M., et al. (2015) A Phase I/II Trial of Interleukin-15-Stimulated Natural Killer Cell Infusion after Haplo-Identical Stem Cell Transplantation for Pediatric Refractory Solid Tumors. Cytotherapy, 17, 1594-1603. https://doi.org/10.1016/j.jcyt.2015.07.011

[71] Iliopoulou, E.G., Kountourakis, P., Karamouzis, M.V., Doufexis, D., Ardavanis, A., Baxevanis, C.N., et al. (2010) A Phase I Trial of Adoptive Transfer of Allogeneic Natural Killer Cells in Patients with Advanced Non-Small Cell Lung Cancer. Cancer Immunology, Immunotherapy, 59, 1781-1789. https://doi.org/10.1007/s00262-010-0904-3

[72] Tonn, T., Schwabe, D., Klingemann, H.G., Becker, S., Esser, R., Koehl, U., et al. (2013) Treatment of Patients with Advanced Cancer with the Natural Killer Cell Line NK-92. Cytotherapy, 15, 1563-1570. https://doi.org/10.1016/j.jcyt.2013.06.017

[73] Suck, G., Odendahl, M., Nowakowska, P., Seidl, C., Wels, W.S., Klingemann, H.G., et al. (2016) NK-92: An 'Off-the-Shelf Therapeutic' for Adoptive Natural Killer Cell-Based Cancer Immunotherapy. Cancer Immunology, Immunotherapy, 65, 485-492. https://doi.org/10.1007/s00262-015-1761-x

[74] Zhu, H., Blum, R.H., Bernareggi, D., Heggernes Ask, E., Wu, Z., Hoel, H.J., et al. 
(2020) Metabolic Reprograming via Deletion of CISH in Human iPSC-Derived NK Cells Promotes in Vivo Persistence and Enhances Anti-Tumor Activity. Cell Stem Cell, 27, 224-237.e226. https://doi.org/10.1016/j.stem.2020.05.008

[75] Knorr, D.A., Ni, Z., Hermanson, D., Hexum, M.K., Bendzick, L., Cooper, L.J., et al. (2013) Clinical-Scale Derivation of Natural Killer Cells from Human Pluripotent Stem Cells for Cancer Therapy. Stem Cells Translational Medicine, 2, 274-283. https://doi.org/10.5966/sctm.2012-0084

[76] Woll, P.S., Grzywacz, B., Tian, X., Marcus, R.K., Knorr, D.A., Verneris, M.R., et al. (2009) Human Embryonic Stem Cells Differentiate into a Homogeneous Population of Natural Killer Cells with Potent in Vivo Antitumor Activity. Blood, 113, 6094-6101. https://doi.org/10.1182/blood-2008-06-165225

[77] Woll, P.S., Martin, C.H., Miller, J.S. and Kaufman, D.S. (2005) Human Embryonic Stem Cell-Derived NK Cells Acquire Functional Receptors and Cytolytic Activity. Journal of Immunology, 175, 5095-5103.

https://doi.org/10.4049/jimmunol.175.8.5095

[78] Han, J., Chu, J., Keung Chan, W., Zhang, J.Y., Wang, Y.W., Cohen, J.B., et al. (2015) CAR-Engineered NK Cells Targeting Wild-Type EGFR and EGFRvIII Enhance Killing of Glioblastoma and Patient-Derived Glioblastoma Stem Cells. Scientific Reports, 5, Article No. 11483. https://doi.org/10.1038/srep11483

[79] Müller, N., Michen, S., Tietze, S., Töpfer, K., Schulte, A., Lamszus, K., et al. (2015) Engineering NK Cells Modified with an EGFRvIII-Specific Chimeric Antigen Receptor to Overexpress CXCR4 Improves Immunotherapy of CXCL12/SDF-1 $\alpha$-Secreting Glioblastoma. Journal of Immunotherapy, 38, 197-210. https://doi.org/10.1097/CJI.0000000000000082

[80] Kruschinski, A., Moosmann, A., Poschke, I., Norell, H., Chmielewski, M., Seliger, B., et al. (2008) Engineering Antigen-Specific Primary Human NK Cells against HER-2 Positive Carcinomas. Proceedings of the National Academy of Sciences of the United States of America, 105, 17481-17486.

https://doi.org/10.1073/pnas.0804788105

[81] Montagner, I.M., Penna, A., Fracasso, G., Carpanese, D., Pietà, A.D., Barbieri, V., et al. (2020) Anti-PSMA CAR-Engineered NK-92 Cells: An Off-the-Shelf Cell Therapy for Prostate Cancer. Cells, 9, 1382. https://doi.org/10.20944/preprints202005.0259.v1

[82] Xia, N., Pang, H.P., Gong, J., Lu, J., Chen, Z.J., Zheng, Y.F., et al. (2019) Robo1-Specific CAR-NK Immunotherapy Enhances Efficacy of ${ }^{125}$ I Seed Brachytherapy in an Orthotopic Mouse Model of Human Pancreatic Carcinoma. Anticancer Research, 39, 5919-5925. https://doi.org/10.21873/anticanres.13796

[83] Blidner, A.G., Mariño, K.V. and Rabinovich, G.A. (2016) Driving CARs into Sweet Roads: Targeting Glycosylated Antigens in Cancer. Immunity, 44, 1248-1250. https://doi.org/10.1016/j.immuni.2016.06.010

[84] Posey Jr., A.D., Schwab, R.D., Boesteanu, A.C., Steentoft, C., Mandel, U., Engels, B., et al. (2016) Engineered CAR T Cells Targeting the Cancer-Associated Tn-Glycoform of the Membrane Mucin MUC1 Control Adenocarcinoma. Immunity, 44, 1444-1454. https://doi.org/10.1016/j.immuni.2016.05.014

[85] Chu, J., Deng, Y., Benson, D.M., He, S., Hughes, T., Zhang, J., et al. (2014) CS1-Specific Chimeric Antigen Receptor (CAR)-Engineered Natural Killer Cells Enhance in Vitro and in Vivo Antitumor Activity against Human Multiple Myeloma. Leukemia, 28, 917-927. https://doi.org/10.1038/leu.2013.279

[86] Li, Y., Hermanson, D.L., Moriarity, B.S. and Kaufman, D.S. (2018) Human 
iPSC-Derived Natural Killer Cells Engineered with Chimeric Antigen Receptors Enhance Anti-Tumor Activity. Cell Stem Cell, 23, 181-192.e185. https://doi.org/10.1016/j.stem.2018.06.002

[87] Souza-Fonseca-Guimaraes, F., Cursons, J. and Huntington, N.D. (2019) The Emergence of Natural Killer Cells as a Major Target in Cancer Immunotherapy. Trends in Immunology, 40, 142-158. https://doi.org/10.1016/j.it.2018.12.003

[88] Park, J., Wrzesinski, S.H., Stern, E., Look, M., Criscione, J., Ragheb, R., et al. (2012) Combination delivery of TGF- $\beta$ Inhibitor and IL-2 by Nanoscale Liposomal Polymeric Gels Enhances Tumour Immunotherapy. Nature Materials, 11, 895-905. https://doi.org/10.1038/nmat3355

[89] Otegbeye, F., Ojo, E., Moreton, S., Mackowski, N., Lee, D.A., de Lima, M., et al. (2018) Inhibiting TGF-Beta Signaling Preserves the Function of Highly Activated, in Vitro Expanded Natural Killer Cells in AML and Colon Cancer Models. PLoS ONE, 13, e0191358. https://doi.org/10.1371/journal.pone.0191358

[90] Young, A., Ngiow, S.F., Gao, Y., Patch, A.-M., Barkauskas, D.S., Messaoudene, M., et al. (2018) A2AR Adenosine Signaling Suppresses Natural Killer Cell Maturation in the Tumor Microenvironment. Cancer Research, 78, 1003-1016. https://doi.org/10.1158/0008-5472.CAN-17-2826

[91] Tchou, J., Zhao, Y., Levine, B.L., Zhang, P.J., Davis, M.M., Joseph Melenhorst, J., et al. (2017) Safety and Efficacy of Intratumoral Injections of Chimeric Antigen Receptor (CAR) T Cells in Metastatic Breast Cancer. Cancer Immunology Research, 5, 1152-1161. https://doi.org/10.1158/2326-6066.CIR-17-0189

[92] Priceman, S.J., Tilakawardane, D., Jeang, B., Aguilar, B., Murad, J.P., Park, A.K., et al. (2018) Regional Delivery of Chimeric Antigen Receptor-Engineered T Cells Effectively Targets HER2 ${ }^{+}$Breast Cancer Metastasis to the Brain. Clinical Cancer Research, 24, 95-105. https://doi.org/10.1158/1078-0432.CCR-17-2041

[93] Nellan, A., Rota, C., Majzner, R., Lester-McCully, C.M., Griesinger, A.M., Mulcahy Levy, J.M., et al. (2018) Durable Regression of Medulloblastoma after Regional and Intravenous Delivery of Anti-HER2 Chimeric Antigen Receptor T Cells. Journal for Immunotherapy of Cancer, 6, 30. http://dx.doi.org/10.1186/s40425-018-0340-Z

[94] Katz, S.C., Point, G.R., Cunetta, M., Thorn, M., Guha, P., Espat, N.J., et al. (2016) Regional CAR-T Cell Infusions for Peritoneal Carcinomatosis Are Superior to Systemic Delivery. Cancer Gene Therapy, 23, 142-148.

https://doi.org/10.1038/cgt.2016.14

[95] Vivier, E., Tomasello, E., Baratin, M., Walzer, T. and Ugolini, S. (2008) Functions of Natural Killer Cells. Nature Immunology, 9, 503-510. https://doi.org/10.1038/ni1582

[96] Bachanova, V., Cooley, S., Defor, T.E., Verneris, M.R., Zhang, B., McKenna, D.H., et al. (2014) Clearance of Acute Myeloid Leukemia by Haploidentical Natural Killer Cells Is Improved Using IL-2 Diphtheria Toxin Fusion Protein. Blood, 123, 3855-3863. https://doi.org/10.1182/blood-2013-10-532531

[97] Adotevi, O., Godet, Y., Galaine, J., Lakkis, Z., Idirene, I., Certoux, J.M., et al. (2018) In Situ Delivery of Allogeneic Natural Killer Cell (NK) Combined with Cetuximab in Liver Metastases of Gastrointestinal Carcinoma: A Phase I Clinical Trial. OncoImmunology, 7, Article ID: e1424673. https://doi.org/10.1080/2162402X.2018.1424673

[98] Chinen, T., Kannan, A.K., Levine, A.G., Fan, X.Y., Klein, U., Zheng, Y., et al. (2016) An Essential Role for the IL-2 Receptor in $\mathrm{T}_{\text {reg }}$ Cell Function. Nature Immunology, 17, 1322-1333. https://doi.org/10.1038/ni.3540 
[99] Huntington, N.D., Puthalakath, H., Gunn, P., Naik, E., Michalak, E.M., Smyth, M.J., et al. (2007) Interleukin 15-Mediated Survival of Natural Killer Cells Is Determined by Interactions among Bim, Noxa and Mcl-1. Nature Immunology, 8, 856-863. https://doi.org/10.1038/ni1487

[100] Mortier, E., Woo, T., Advincula, R., Gozalo, S. and Ma, A. (2008) IL-15Ralpha Chaperones IL-15 to Stable Dendritic Cell Membrane Complexes That Activate NK Cells via Trans Presentation. The Journal of Experimental Medicine, 205, 1213-1225. https://doi.org/10.1084/jem.20071913

[101] Hennessy, R.J., Pham, K., Delconte, R., Rautela, J., Hodgkin, P.D. and Huntington, N.D. (2019) Quantifying NK Cell Growth and Survival Changes in Response to Cytokines and Regulatory Checkpoint Blockade Helps Identify Optimal Culture and Expansion Conditions. Journal of Leukocyte Biology, 105, 1341-1354. https://doi.org/10.1002/JLB.MA0718-296R

[102] Strengell, M., Matikainen, S., Sirén, J., Lehtonen, A., Foster, D., Julkunen, I., et al. (2003) IL-21 in Synergy with IL-15 or IL-18 Enhances IFN-Gamma Production in Human NK and T Cells. Journal of Immunology, 170, 5464-5469.

https://doi.org/10.4049/jimmunol.170.11.5464

[103] Lusty, E., Poznanski, S.M., Kwofie, K., Mandur, T.S., Lee, D.A., Richards, C.D., et al. (2017) IL-18/IL-15/IL-12 Synergy Induces Elevated and Prolonged IFN- $\gamma$ Production by ex Vivo Expanded NK Cells Which Is Not Due to Enhanced STAT4 Activation. Molecular Immunology, 88, 138-147.

https://doi.org/10.1016/j.molimm.2017.06.025

[104] Assmann, N., O’Brien, K.L., Donnelly, R.P., Dyck, L., Zaiatz-Bittencourt, V., Loftus, R.M., et al. (2017) Srebp-Controlled Glucose Metabolism Is Essential for NK Cell Functional responses. Nature Immunology, 18, 1197-1206.

https://doi.org/10.1038/ni.3838

[105] Sukumar, M., Liu, J., Ji, Y., Subramanian, M., Crompton, J.G., Yu, Z.Y., et al. (2013) Inhibiting Glycolytic Metabolism Enhances CD8 ${ }^{+} \mathrm{T}$ Cell Memory and Antitumor Function. The Journal of Clinical Investigation, 123, 4479-4488. https://doi.org/10.1172/JCI69589

[106] Crompton, J.G., Sukumar, M., Roychoudhuri, R., Clever, D., Gros, A., Eil, R.L., et al. (2015) Akt Inhibition Enhances Expansion of Potent Tumor-Specific Lymphocytes with Memory Cell Characteristics. Cancer Research, 75, 296-305. https://doi.org/10.1158/0008-5472.CAN-14-2277

[107] Naeimi Kararoudi, M., Dolatshad, H., Trikha, P., Hussain, S.-R.A., Elmas, E., Foltz, J.A., et al. (2018) Generation of Knock-Out Primary and Expanded Human NK Cells Using Cas9 Ribonucleoproteins. Journal of Visualized Experiments, No. 136, 58237. https://doi.org/10.3791/58237

[108] Wang, Q.M., Tang, P.M., Lian, G.Y., Li, C.J., Li, J.H., Huang, X.-R., et al. (2018) Enhanced Cancer Immunotherapy with Smad3-Silenced NK-92 Cells. Cancer Immunology Research, 6, 965-977. https://doi.org/10.1158/2326-6066.CIR-17-0491

[109] Esser, R., Müller, T., Stefes, D., Kloess, S., Seidel, D., Gillies, S.D., et al. (2012) NK Cells Engineered to Express a GD2 -Specific Antigen Receptor Display Built-in ADCC-Like Activity against Tumour Cells of Neuroectodermal Origin. Journal of Cellular and Molecular Medicine, 16, 569-581. https://doi.org/10.1111/j.1582-4934.2011.01343.x

[110] Sahm, C., Schönfeld, K. and Wels, W.S. (2012) Expression of IL-15 in NK Cells Results in Rapid Enrichment and Selective Cytotoxicity of Gene-Modified Effectors That Carry a Tumor-Specific Antigen Receptor. Cancer Immunology, Immunotherapy, 61, 
1451-1461. https://doi.org/10.1007/s00262-012-1212-x

[111] Zhang, C., Burger, M.C., Jennewein, L., Genßler, S., Schönfeld, K., Zeiner, P., et al. (2016) ErbB2/HER2-Specific NK Cells for Targeted Therapy of Glioblastoma. Journal of the National Cancer Institute, 108, djv375. https://doi.org/10.1093/jnci/djv375

[112] Arai, S., Meagher, R., Swearingen, M., Myint, H., Rich, E., Martinson, J., et al. (2008) Infusion of the Allogeneic Cell Line NK-92 in Patients with Advanced Renal Cell Cancer or Melanoma: A Phase I Trial. Cytotherapy, 10, 625-632. https://doi.org/10.1080/14653240802301872

[113] Yuan, X., Wu, H., Bu, H., Zhou, J. and Zhang, H. (2019) Targeting the Immunity Protein Kinases for Immuno-Oncology. European Journal of Medicinal Chemistry, 163, 413-427. https://doi.org/10.1016/j.ejmech.2018.11.072

[114] Yingling, J.M., McMillen, W.T., Yan, L., Huang, H., Scott Sawyer, J., Graff, J., et al. (2018) Preclinical Assessment of Galunisertib (LY2157299 Monohydrate), a First-in-Class Transforming Growth Factor- $\beta$ Receptor Type I Inhibitor. Oncotarget, 9, 6659-6677. https://doi.org/10.18632/oncotarget.23795

[115] Spolski, R., Li, P. and Leonard, W.J. (2018) Biology and Regulation of IL-2: From Molecular Mechanisms to human Therapy. Nature Reviews Immunology, 18, 648-659. https://doi.org/10.1038/s41577-018-0046-y 